the lake. Off the station of Mabagi, on the north-west shore of the lake, Dr. Junker found a long, low, sandy island, which he recognized as of quite recent formation; for in 1879 he noticed that the spot where it now lies was covered with shallow water. Its length is 1067 yards, and maximum breadth 99 yards. Tall grass and weeds grow at the water's edge, and a species of acacia $(A$. mellifera) on the higher parts. The island, Emin Pasha states, is due to the deposition of the detritus brought down by the two rivers which enter from the south-west. From what he observed on the lake, he is inclined to believe that the foreshore on the west is gradually encroaching on its waters ; in other words, the lake in this part is gradually filling up. As for the lake itself, Emin Pasha attributes its origin solely to erosion. He thinks it more than probable that formerly a large stream may have made its way from between the two ranges to east and west of the lake, so that its erosive action, combined with that of inundations, heavy rains, caving-in, and the influence of the sun and weather, are quite sufficient to account for the result. The geological formation of both ranges is the same ; their altitudes differ but little, and the terrace-like formation of their descent lakewards is in each case exactly alike. Emin Pasha hoped to examine the problem much more minutely. He landed at Kibiro, on the opposite side of the lake, and gives an interesting description of the valuable salt-mines of the region. Emin Pasha afterwards made two other journeys on the lake, during one of which he discovered what he believes to be a new river, called Kakibbi by the Wasongora, and Duéru by the Wamboga. It flows from the Ussongora Mountains, and is of considerable size, and enters the lake at the south, having a large island near its embouchure. It abounds with cataracts, and is therefore unnavigable. To the south-west, Emin Pasha was informed, there is a large river on the banks of which there is a colony of Akkas-called Balia by the Wanyoro people, but by themselves Betua; the latter a name suggesting the Batua recently discovered by Lieut. Wolf on the Sankuru, to the south of the Congo. Is it not possible that the Kakibbi is the same as the "red river" discovered by Mason Bey in 1877 , entering the south extremity of Lake Albert?

In the Bulletin of the Lyons Anthropological Society will be found an interesting paper by M. Bertholon on the "Arab Colonization of France," in which the author, mainly on the basis of place-names, seeks to identify the existing effects of the Saracenic invasion of France. Dr. Collomb has also a useful paper on the peoples of the Upper Niger, their manners and their history.

M. Edouard Dupont, Director of the Brussels Natural History Museum, is about to leave for the Congo, to make a geological investigation of the region along the south bank of the river, between Boma and Stanley Posl. He will endeavour especially to determine the epoch when the river broke through the coast range, and the age of these mountains. He will also explore any caves which may exist, in order to discover if there are any remains of a primitive population.

THE new number of Petermann's Mitteilungen is one of special scientific intere: $t$. The first paper gives the results of a series of researches by Japanese botanists on the botanical zones of Japan, in which the relation of these zones is shown to the configuration of the surface of the country. A much longer and perhaps more important paper in the same department is Herr Ernst Hartert's account of the botanical results of the expedition to the Niger under the late Herr Flegel; it abounds with detailed information on the plants collected by the expedition. Dr. Alex. Supan, the able editor of the Mitteilungen, who takes a special interest in meteorology, contributes a carefully elaborated paper on the mean duration of the chief heat periods in Europe. Then we have a series of extracts from Emin Pasha's letters, from 1883 down to 1886 , much of which has already been published.

THE NEPHRIDIA OF " LANICE CONCHILEGA," MALMGREN."

SEVERAL accounts of the nephridia of Terebella conchilega have been given. H. Milne-Edwards (Ann. d. Sci. Nat. (2) Zoologie, x, 1838 , p. 220), in a paper published in 1838 , on the circulation in Annelids, describes the vascular system in a species to which he gives this name, and gives a

I A Paper read before the Royal Society of Edinburgh by Mr. J. T. Cunningham, on Monday, May 16 . figure of the animal opened along the dorsal median line. In this figure four looped nephridia are distinctly shown, situated behind the branchial region. The representation of the position and character of these organs is perfectly correct so far as it goes : they are the upper parts of the four nephridia belonging to somites 6-9. But the paper I refer to does not describe the nephridia, as it deals with another subject: they are shown in the figure, and that is all ; and in the description of the figure the organs are referred to as organs of generation.

Keferstein (Zitschrift fïr wiss. Zoologie, Bd. xii., 1862) mentions that the structure and number of the nephridia in $T$. conchilega are the same as in $T$. gelatinosa, Kef.: in both cases he says there are six pairs, each organ consisting of a tube bent on itself, of which one half is darker, the other lighter: the organs belong to segments $3-9$.

Cosmovici ${ }^{1}$ gives an erroneous description of the organs : he says there are two pairs without internal openings, which he calls " organs of Bojanus," one of these situated in front of the cephalic diaphragm, the other immediately behind it, each organ having an external opening; and two other pairs, each of which has an internal as well as external opening, and is shaped like an urn : the internal opening is large, and surrounded with a circular lip. The gonad is attached to the posterior part of ench of these latter organs, which Cosmovici calls segmental organs, and which he says serve as efferent excretory ducts.

The species referred to by these three authors is the Nereis conchilega of Pallas, Terebella conchilega of Gmelin; and this is called Lanire conchilega by Malmgren. My specimens were identified from Malmgren's description, and there is no doubt of the identity of my specimens with the species of that author; but there is room for some uncertainty regarding the specific identity of the specimens referred to by the authors I have mentioned. For instance, Cosmovici identified his species by means of Quatrefages' "Histoire des Annelés," 1865, and there it is stated that the tube of Terebella conchilega possesses no hollow fringes at its mouth: these fringes are always present in the tube of Lanise conchilega, Malmgren. This species is distinguished by some marked characters : two of them are the presence of a large vertical lobe on the $3^{\text {rd }}$ somite (second branchiferous) and the coalescence of the ventral scutes usually present into a continuous ventral plate.

The true relations of the excretory system are as follow:Enumerating the somites from before backwards, and counting the buccal as the Ist, we find that the branchiæ belong to somites 2, 3, and 4: the first notopodial fascicle of capillary setre is on the $4^{\text {th }}$ somite, the third branchiferous; the first neuropodial uncinigerous torus is on the 5 th : the neuropodial tori are repeated on every succeeding somite to the end of the body; the notopodial fascicles occur only on seventeen consecutive somites. There are trace; of transverse septa behind the Ist, 2nd, 3 rd, and $4^{\text {th }}$ somites, but none in the rest of the thoracic region, which bears the notopodial fascicles. On dissection, four long double nephridial tubes are seen projecting dorsalwards with the body-cavity; the lower parts of these tubes are covered by stranits of the oblique muscles which pass from the nerve cord to the neighbourhood of the notopodial bristles : careful examination shows that these tubes belong to somites $6,7,8$, and 9. Their internal openings can be found immediately behind the fascicle of bristles belonging to somites 5,6 , 7 , and 8 respectively, but their efferent tubes are seen to pass down beneath the fascicles of somites $6,7,8$, and 9 . The lower parts of these efferent tubes are very wide, and it is impossible to separate them from one another. Beneath the fascicles of the following four somites (IO-13 inciusive) are seen membranous nephridial sacs, which externally at least are inseparable from one another. These sacs are simple, that is, they are not com. posed of a tube bent on itself like the anterior nephridia: they scarcely extend above the level of the oblique muscles, and no internal opening or nephrostome can be found in them. In front of the $\mathrm{m}$ st anterior nephridium, that belonging to somite 6 , are seen traces of a rudimentary nephridium. In order to trace out the relations of these nephridia more accurately, the anterior part of a specimen was cut into a series of horizontal longitudinal sections, commencing with the ventral surface, and the reason why the successive nephridia could not be isolated from one another was seen on examination of these sections : the lower parts of the efferent limbs of the four anterior normal nephridia, in somites 6-9, and the whole of the nephridial sacs in somites

I "Glandes génitales et Organes segmentaires des Annélides polychètes" (Arch. de Zoot. Exp., t. viii., I879-80). 
10-13, are in open communication, forming a wide continuous longitudinal tube extending from somite 6 to somite 13 . Openings to the exterior from this tube were found in somites 6-9 inclusive, corresponding to the four large looped nephridia : each of these openings was close behind the upper end of an uncinigerous torus. The internal openings of the same four nephridia could be traced with ease and certainty: they are attached to the body-wall close behind the notopodial fascicles of somites $5-8$. These openings are wide, and are overhung dorsally by a longitudinal lip furnished with a series of small ciliated digitate processes : lower down, the anterior and posterior lips of the opening are simple, thick-walled, and ciliated. The aperture leads into a thin tube, which passes inwards and backwards, curving round the inner end of the fascicle of bristles behind the aperture, and then, crossing the continuous tube, passes up on the inner or medial side of the loop, at the apex of which it is continued into the efferent wider limb of the loop, which passes down on the outer side to open into the longitudinal tube. Neither internal nor external openings could be found in that part of the longitudinal tube which is behind the loops: it seems evident that this part of the tube represents four somewhat reduced nephridia which have coalesced, but whose openings have disappeared. Anteriorly to the four looped nephridi i are traces of three others : the longitudinal tube extends forwards into somite 5 as if it included a nephridium belonging to that somite, but I could find no external opening in this somite: at the angle between the septum behind somite 4 and the body-wall is a very obvious nephrostome, which ought to lead into the longitudinal tube, into that part of it corresponding to somite 5 , but the connexion could not be traced. Nephrostomes were also present attached to the anterior face of the septa behind somites 2 and 3 (the first and second branchiferous), and leading into tubes seen in somites 3 and 4 , but I could find no external openings in these somites. $I$ could find $n$ ) nephrostome in s)mite I (the buccal) nor any trace of a tube in somite 2. Gonads are present in the form of clumps of deeply-staining small indifferent cells attached to the exterior of all the nephrostomata mentioned, seven in all. The germinal cells, when still quite undifferentiated, separate from the gonads, and undergo further development in the colome. But I found no reproductive elements in the cavity of the nephridial system, though the body-cavity contained them in quantity, and it is probable that at the right season they are expelled through the nephridial system. The body-cavity contains, besides the reproductive elements, a large number of spherical, vacuolated, nucleated cells. This is the first case in which a communication between successive nephridia has ever been discovered in any adult invertebrate. It is true that in the development of Polygordius, according to Hatschek, each nephridium gives off backwards a prolongation of itself, from which the next nephridium is fo:med, and the two remain in communication for a time ; but the connexion is soun severed, and in the adult the successive nephridia are isolated and independent. In I anice conchileg. the nephridia have coalesced together after coming in contact from before backwards, the separating membranes having disappeared. The case is extremely interesting in the fact that we have in it an approximation to the condition of the excretory system in Vertebrata: the presence of a metameric series of nephrostomata in vertebrate embryos has long ago been seen to constitute a resemblance between them and Chætopoda, but hitherto no Chætopod was known which resembled the vertebrate in having a number of nephricia coalesced to form a continuous longitudinal tube.

It is surprising to find that, as far as I have been able to discover, no resemblance to the condition seen in Lanice conchilega occurs in any of its near allies. The only species of the genus Terebella as defined by Malmgren that occurs in the Firth of Forth is Terebella Danielsseni, but of this I have only one specimen, and have not examined its nephridia. Of Amphitrite there are two species in the Forth: Amplitr-ite cirrata I have not examined anatomically ; in Amphitrite Johnstoni there are a large number $(15-17)$ of nephridia forming long loops projecting dorsalwards into the body-cavity, in the anterior region: each has its own internal and external openings, and is isolated and independent. In Terebellides Stromii there is one pair of large dark-coloured nephridia in the anterior end, and three pairs of small rudimentary ones posterior to this. In Pectinaria belgica there are three pairs: they are all independent. In Melinna cristata there are several pairs, all separate. Figures showing the interesting relations which exist in Ianice conchilega, together with a more complete description of the nephridia in other forms of Polychrta, will I hope shortly be published in a paper on the anatomy of Polychæta.

\section{NOTES ON THE GEOLOGY OF PART OF THE EASTERN COAST OF CHINA AND THE ADJACENT ISLANDS.}

SURGEON P. W. BASSETT-SMITH, R.N., has forwarded to the Hydrographical Department of the Admiralty a brief Report on this area, embodying the results of ob ervations made in the course of last summer during the cruise of H.M.S. Rambler. Specimens of rocks were collected at certain points on the mainland and on the neighbouring islands, stretching from Chusan on the north to Ockseu Island, south of Hai-tan Strait, opposite the northern part of Formosa.

All the islands, with a single exception, appear to consist of crystalline rocks. They usually present sharp rugged outlines, with bold cliffs-more or less fissured and veined--rising, in many cases, vertically from moderately deep water. In the following notes, the stations from which the specimens were collected are described in succession from north southwards.

Tou-wah Island, the most northerly station, consists of an irregul: $r$ range of hills trending in a north-west and south-east direction, and reaching an elevation of 1600 feet. A gray granitic rock was obtained from the summit. Thornton Peak, on the mainland in the province of Chi-kiang, separated from the Chusan group by a narrow sea, is composed of a pink granite. From Ta-fou Island, in San-moon Bay, a fine-grained purplish quartz-felsite was obtained. The group of Hae-shan Isles seems to be coniposed of a dark gray quartz-felsite, and a similar rock forms the Tai-chow Islands.

Another group of stations visited by the Rambler lies off the coast of the province of Fu-kien. Fuh-yan Island consists of hills reaching a height of $\mathbf{I} 700$ feet, and yielding a fine-grained greenish rock, apparently a diabase. Coney Island is composed for the most part of a coarse pinkish granite, with veins of quartz, and dykes which appear to consist of diabase and hornblende-porphyrite. The two islands known as Tung Yung are formed mainly of quartz.felsite; the specimens obtained from th: larger of the two isles containing much opaque white feldspar, porphyritically distributed through the rock. In a cove at the south-west end of the latter island, the rocks split up into irregular columns, and in certain parts these columns exhibit considerable curvature.

The third group of stations is situated on the River Min, and in the neighbourhood of its mouth. Chang-chi is a large irregular. shaped island of red porphyrite. The island known as Matsou is particularly interestino, the principal rock being a white quartz-felsite, with a complicated network of basaltic dykes. In a small sandy bay, a deep water-course exposes a layer of dark earth, about a foot in thickness, crowded with land shells. Two small neighbouring islands known as White Dog consist of dark gray quartz-felsite.

On the north side of the mouth of the River Min is an island, termed Sharp Peak, about three miles in length, which culminates in a rocky peak I 500 feet high. 'The island is formed, for the most part, of a hard conglomerate, associated with slates and shales, and with a talcose schist penetrated by veins of quartz. A cliff at the north-east point of the island displayed a clear section, in which this schist was seen to alternate with beds of slate and conglomerate, inclined at about $45^{\circ}$.

A small low island off the south point at the entrance to the River Min, consists of granite, gneiss, and mica-schist. A specimen of red granite, with crystals of iron pyrites, was obtained from the rugged mountains of the neighbouring mainland. Temple Point, on the north side of the Min, a few miles from its mouth, yielded a greenish-yellow steatitic rock, with dendritic markings. At Pagoda Anchorage, up the river, a finegrained pink gneiss was obtained, and this locality also yielded a fragment of a large crystal of smoky quartz. About twelve miles further up the Yuen Fu branch of the Min River are some hot springs having a miximum temperature, in November, of $14^{\circ} \mathrm{F}$. The rock is here a quartz-felsite. An orthoclase porphyry occurs about five miles further up the river, and quartzfelsite again occurred ten miles higher. Here, in a curious recess in the hill-side, in which a temple has been built, are numerous stalactites, some of large size. The mountains all up 